\title{
KARAKTERISTIK KEPEMIMPINAN KIAI GENERASI KETUJUH DI PONDOK PESANTREN RIYADLUL ULUM WADDA'WAH TASIKMALAYA
}

\author{
1)Cecep Hasib, 2)Husaini Usman \\ 1)Yayasan Pendidikan Islam Al-Jihad Sindangreret, Tamanjaya Tamansari Kota Tasikmalaya, \\ 2)Prodi Pendidikan Teknik Sipil dan Perancanaan Universitas Negeri Yogyakarta \\ 1)cecep.hasib87@gmail.com, 2)husaini_usman@uny.ac.id
}

\begin{abstract}
Abstrak
Penelitian ini bertujuan untuk mendapatkan deskripsi tentang karakteristik kepemimpinan Kiai generasi ketujuh di Pondok Pesantren Riyadlul Ulum Wadda'wah Tasikmalaya. Deskripsi tersebut meliputi: kepribadian, motivasi, keterampilan, dan karakteristik dominan. Penelitian ini adalah penelitian fenomenologi dengan pendekatan kualitatif. Pengumpulan data dilakukan dengan wawancara, observasi, dan dokumentasi. Teknik analisis data menggunakan model interaktif Miles \& Huberman. Hasil penelitian: (1) Karakteristik kepribadian kepemimpinan kiai yaitu tawadhu, dibuktikan dengan sikap kiai yang tidak ingin diposisikan sebagai orang yang memiliki otoritas penuh terhadap segala sesuatu, seperti mengizinkan santrinya untuk menjadi imam shalat fardhu dan khatib shalat Jum'at. (2) Karakteristik motivasi kepemimpinan kiai meliputi motivasi intrinsik dan ekstrinsik. Motivasi intrinsik yaitu kewajiban untuk terus berdakwah lii'laikalimaatillah. Motivasi ekstrinsik yaitu untuk menjalankan amanat dan kepercayaan masyarakat. (3) Keterampilan yang dikuasai oleh kiai meliputi: keterampilan teknis, seperti mengajar, bertani/berkebun, dan beternak; keterampilan interpersonal seperti menjadi teladan dalam beribadah; keterampilan konseptual seperti memunculkan gagasan-gagasan baru dalam pendidikan dan pengajaran. (4) Karakteristik dominan kiai yaitu: tawadhu dan amanah.
\end{abstract}

Kata Kunci: karakteristik kepemimpinan, kepemimpinan kiai

\section{THE CHARACTERISTIC OF THE SEVENTH GENERATION KIAI'S LEADERSHIP IN RIYADLUL ULUM WADDA'WAH ISLAMIC BOARDING SCHOOL TASIKMALAYA}

\author{
1)Cecep Hasib, 2)Husaini Usman \\ 1)Yayasan Pendidikan Islam Al-Jihad Sindangreret, Tamanjaya Tamansari Kota Tasikmalaya, \\ 2)Prodi Pendidikan Teknik Sipil dan Perancanaan Universitas Negeri Yogyakarta \\ 1)cecep.hasib87@gmail.com, ${ }^{2}$ husaini_usman@uny.ac.id
}

\begin{abstract}
This research aims to obtain a description of the characteristics of the seventh generation Kiai's leadership in Islamic Boarding School of Riyadlul Ulum Wadda'wah Tasikmalaya. The descriptions include: personality, motivation, skills, and dominant characteristics. This is empirical research with a qualitative approach with phenomenology. Data were collected by interviews, observation, and documentation, and then analyzed using data analysis Miles $\mathcal{E}$ Huberman interactive model techniques. The results of this research are: (1) The characteristic of leadership personalities of Kiai is tawadhu. It is evidenced by kiai's attitude that doesn't want to be positioned as a man has a full directionary to the everythings, such as allowing his santri to become fardhu prayer leader and khatib in Friday prayer. (2) Leadership characteristics motivation of Kiai includes intrinsic and extrinsic motivation. Intrinsic motivation occurs because the obligation to continue to preach lii'laikalimaatillah. The extrinsic motivation are to execute the mandate and public confidence. (3) The skills that are mastered by Kiai include: technical skill, such as teaching, farming/gardening, and livestock; interpersonal skills as an example in worship; conceptual skills as bring new ideas in education and teaching. (4) The dominant characteristics of Kiai are: tawadhu and amanah.
\end{abstract}

Keywords: leadership characteristic, leadership of kiai 


\section{Pendahuluan}

Peraturan Menteri Agama Nomor 18 Tahun 2014 tentang Satuan Pendidikan Muadalah pada Pondok Pesantren pasal 1 ayat 2 menyebutkan "Pendidikan keagamaan Islam adalah pendidikan yang mempersiapkan peserta didik untuk dapat menjalankan peranan yang menuntut penguasaan pengetahuan tentang ajaran agama Islam dan/atau menjadi ahli ilmu agama Islam dan mengamalkan ajaran agama Islam."

Pondok pesantren merupakan lembaga pendidikan Islam tertua di nusantara. Selain itu, pondok pesantren juga memiliki peranan penting dalam pembentukan da'ida'i dan penanaman nilai-nilai keagamaan di masyarakat, karena pondok pesantren merupakan lembaga pendidikan yang didirikan berdasarkan inisiatif masyarakat. Peraturan Menteri Agama nomor 18 tahun 2014 tentang Satuan Pendidikan Muadalah pada Pondok Pesantren, pasal 1 ayat 3 menyebutkan "Pondok pesantren yang selanjutnya disebut pesantren adalah lembaga pendidikan keagamaan Islam yang diselenggarakan oleh masyarakat yang menyelenggarakan satuan pendidikan pesantren dan/atau secara terpadu menyelenggarakan jenis pendidikan lainnya."

Pondok pesantren tersebar di seluruh wilayah Indonesia, termasuk di wilayah Jawa Barat. Berdasarkan rekapitulasi data pondok pesantren yang diperoleh dari Kementerian Agama Provinsi Jawa Barat tahun 2014, terdapat 8.231 pondok pesantren yang ada di wilayah Jawa Barat. Jawa Barat terdiri dari 26 Kabupaten/Kota, yang salah satunya adalah Kota Tasikmalaya. Di kota tersebut terdapat 237 pondok pesantren yang tersebar di 10 kecamatan. Dari 237 pondok pesantren, terdapat salah satu pondok pesantren yang memiliki reputasi baik, yaitu Pondok Pesantren Riyadlul Ulum Wadda' wah.

Pondok Pesantren Riyadlul Ulum Wadda'wah yang lebih terkenal dengan nama Pondok Pesantren Condong ini merupakan salah satu pondok pesantren tertua di Kota Tasikmalaya. Berdasarkan catatan sejarah yang dipublikasikan oleh pondok tersebut, bahwa Pondok Pesantren Riyadlul Ulum Wadda'wah didirikan sekitar abad ke-18. Keterangan itu dibuktikan dengan ditemukannya wakaf tanah seluas 400 tumbak dari Pangeran Kornel Sumedang. Tanah wakaf itu berlokasi di Kampung Condong RT.01 RW.04 Kelurahan Setianegara Kecamatan Cibeureum Kota Tasikmalaya yang merupakan lokasi Pondok Pesantren Riyadlul Ulum Wadda'wah saat ini.

Sistem pendidikan yang diusung oleh Pondok Pesantren Riyadlul Ulum Wadda'wah adalah pola pendidikan terpadu. Sistem ini memiliki cita-cita mulia untuk membina generasi muda Indonesia menjadi generasi yang kaffah dan bermanfaat bagi dirinya dan masyarakat. Landasan-landasan yang dikolaborasikan menjadi sebuah sistem pendidikan terpadu (integrated education system) pada pondok pesantren tersebut.

Visi Pondok Pesantren Riyadlul Ulum Wadda'wah adalah "Membangun insan paripurna yang berakhlakul karimah, berwawasan ilmiyah, dan memiliki daya saing dalam menghadapi era globalisasi yang dilandasi oleh ilmu amaliyah, amal ilmiyah, dan motto hidup sekali hiduplah yang berarti." Sedangkan misinya yaitu: (1) menanamkan akidah yang kuat; (2) memiliki jiwa kesederhanaan dan kemandirian; (3) memperkuat ukhuwah islamiyah, wathaniah, dan basyaria; (4) berpikir luas, kreatif, dan inovatif; (5) menjunjung tinggi nilainilai kejujuran, keadilan, dan kebenaran.

Pondok Pesantren Riyadlul Ulum Wadda'wah Tasikmalaya yang merupakan salah satu pondok pesantren terbesar di Kota Tasikmalaya terus mengalami perkembangan dari tahun ke tahun. Hal itu ditunjukan dengan bertambahnya jenjang pendidikan formal dan nonformal. Namun demikian, masih ada keinginan dari pondok pesantren tersebut yang belum terlaksana yaitu pendidikan Ma'had Aly.

Pendidikan Ma'had Aly sebenarnya pernah dilaksanakan namun mengalami kendala. Kendala itu dikarenakan ketidakjelasan legalitas Ma'had Aly di Indonesia, sehingga pimpinan pondok pesantren me- 
lakukan memorendum of understanding dengan Institut Agama Islam Cipasung (IAIC) Tasikmalaya. Namun kerja sama itu tidak bertahan lama, sehingga pendidikan $M a^{\prime} h a d$ Aly tidak dapat berlangsung dan mahasiswa yang ada harus berpindah ke IAIC Tasikmalaya atau ke perguruan tinggi lain. Dalam kasus ini, pimpinan pondok pesantren mengalami kendala dalam melaksanakan program pendidikan Ma'had Aly.

Pondok pesantren Riyadlul Ulum Wadda'wah Tasikmalaya telah memenuhi jumlah tenaga pendidik yang dibutuhkan sebagai respon dari meningkatnya jumlah santri. Sebagai bentukpemenuhan kebutuhan tenaga pendidik, maka pimpinan pondok pesantren tersebut merekrut dua jenis tenaga pendidik, yaitu tenaga pendidik yang berasal dari dalam dan luar pondok pesantren Riyadlul Ulum Wadda'awah Tasikmalaya. Tenaga pendidik dari dalam pondok pesantren adalah alumni dari pondok pesantren tersebut, sedangkan yang dari luar adalah tenaga pendidik yang bukan alumni pondok tersebut tetapi sengaja datang untuk mengajar pada jam sekolah formal saja. Kedua jenis guru ini memiliki perbedaan dalam melaksanakan kedisiplinan yang diterapkan, terutama guru dari luar masih ada yang melanggar tata tertib pondok pesantren.

Pelanggaran yang dilakukan oleh guru dari luar berupa keterlambatan datang ke sekolah atau membolos. Hal itu disebabkan oleh jarak tempuh dari rumah ke pondok pesantren cukup jauh. Keadaan seperti itu menjadi hambatan bagi para guru dan juga penerapan kedisiplinan guru. Namun demikian, sanksi berupa teguran sampai dengan skorsing sudah dilakukan oleh pimpinan pondok pesantren. Namun demikian, keadaan ini dapat membuktikan bahwa langkah yang dilakukan oleh pimpinan pondok pesantren dalam mendisiplinkan para guru masih belum efektif.

Pencapaian yang diraih oleh Pondok Pesantren Riyadlul Ulum Wadda'wah tidak terlepas dari peran pemimpin pondok pesantren. Pemimpin pondok pesantren yang kemudian disebut kiai merupakan tokoh sentral yang menggerakan kegiatan pondok pesantren. Pada dasarnya baik atau buruknya sebuah lembaga tergantung pada kepemimpinannya. Menurut Peters \& Austin (Usman, 2013, p.436), faktor yang menentukan mutu dalam sebuah lembaga adalah kepemimpinan.

Pemimpin dalam sebuah lembaga pendidikan pondok pesantren disebut kiai, sehingga dapat dinyatakan bahwa baik maupun buruknya sebuah pondok pesantren tergantung pada kepemimpinan kiai. Lebih lanjut dikemukakan oleh Dhofier (2011, p.93) yang menyatakan bahwa pertumbuhan suatu pesantren semata-mata bergantung pada kemampuan pribadi kiainya.

Kepemimpinan di Pondok Pesantren Riyadlul Ulum Wadda'wah telah memasuki generasi ketujuh. Dengan urutan pemimpin pondok dari generasi ke generasi disajikan pada Tabel 1.

Tabel 1. Nama Pemimpin Pondok Pesantren Riyadlul Ulum Wadda'awah Tasikmalaya dari Generasi ke Generasi.

\begin{tabular}{cll}
\hline $\begin{array}{c}\text { Generasi } \\
\text { Ke- }\end{array}$ & $\begin{array}{c}\text { Inisial } \\
\text { Pemimpin }\end{array}$ & Tahun Menjabat \\
\hline 1 & KH. N & $\begin{array}{l}\text { Sekitar abad ke-18 s/d } \\
\text { tdk diketahui }\end{array}$ \\
2 & KH. A & Tidak diketahui pasti \\
3 & KH. HM & Tidak diketahui pasti \\
4 & KH. D & $\begin{array}{l}\text { Tidak diketahui pasti } \\
\text { s d 1935 }\end{array}$ \\
5 & KH. N & 1935 s/d 1986 \\
6 & KH. M & 1986 s/d 2014 \\
7 & KH. DDF & 2014 s/d sekarang \\
\hline
\end{tabular}

Sumber: Selayang Pandang Pondok Pesanren Condong (Syihabuddin \& Romadhoni, (2015)

Tujuh generasi itu dibagi menjadi dua periode yaitu periode Condong lama dan periode Condong baru. Periode Condong lama berada di bawah kepemimpinan generasi pertama sampai generasi keempat, yaitu sejak berdiri (tidak diketahui tahun pastinya) sampai tahun 1917. Adapun periode Condong baru mulai dari generasi kelima sampai ketujuh yaitu tahun 1917 sampai sekarang. 
Saat ini pemimpin pondok pesantren dipimpin oleh generasi ketujuh. Pemimpin generasi ketujuh mulai memimpin pada tahun 2014. Pemimpin pondok pesantren generasi ketujuh ini merupakan putra keempat dari pemimpin pondok pesantren sebelumnya. Beliau merupakan anak lakilaki tertua dari sebelas bersaudara.

Riwayat pendidikan yang ditempuh oleh pemimpin generasi ketujuh meliputi pendidikan formal dan nonformal. Pendidikan formal dimulai dari Sekolah Dasar (SD) sampai dengan Sekolah Menengah Atas (SMA). Adapun pendidikan nonformal yaitu pendidikan di beberapa pondok pesantren yang ada di Jawa Barat. Riwayat pendidikan pemimpin Pondok Pesantren Riyadlul Ulum Wadda'wah dapat dilihat pada Tabel 2.

Tabel 2. Riwayat Pendidikan Pemimpin Generasi Ketujuh Pondok Pesantren Riyadlul Ulum Wadda'wah

\begin{tabular}{|c|c|}
\hline \multicolumn{2}{|c|}{ Pendidikan Formal } \\
\hline Nama Lembaga & $\begin{array}{l}\text { Tahun } \\
\text { Belajar }\end{array}$ \\
\hline SDN Cibeureum & $1959-1965$ \\
\hline SMPN 13 Tasikmalaya & 1965-1969 \\
\hline SMA Islam Cipasung & 1969-1971 \\
\hline \multicolumn{2}{|c|}{$\begin{array}{l}\text { Pendidikan Nonformal/Pondok } \\
\text { Pesantren }\end{array}$} \\
\hline Nama Lembaga & $\begin{array}{l}\text { Tahun } \\
\text { Belajar }\end{array}$ \\
\hline Cipasung, Tasikmalaya & $1969-1971$ \\
\hline Cikalama, Sumedang & $1972-1974$ \\
\hline Riyadlul Alfiyah, Garut & 1974-1975 \\
\hline Bojongsari, Tasikmalaya & 1975-1976 \\
\hline $\begin{array}{l}\text { Miftahul Huda Islamiyah, } \\
\text { Ciamis }\end{array}$ & 1976-1977 \\
\hline Bojongsari, Tasikmalaya & 1977-1982 \\
\hline $\begin{array}{c}\text { amber:Biografi } \text { Pemimpin } \\
\text { Pondok Pesantren } \\
\text { Wadda'wah, } 2016\end{array}$ & $\begin{array}{l}\text { enerasi Ket } \\
\text { Riyadlul U }\end{array}$ \\
\hline
\end{tabular}

Berdasarkan prasurvei, peneliti menemukan beberapa keunikan yang dimiliki oleh pemimpin Pondok Pesantren Riyadlul Ulum Wadda'wah Tasikmalaya. Pertama, sistem pendidikan yang dimiliki oleh oleh pondok pesantren tersebut yaitu sistem pendidikan khalafi. Artinya, pendidikan yang diterapkan yaitu memadukan pengetahuan agama dengan pengetahuan umum, padahal latar belakang pendidikan pemimpin pondok pesantren cenderung pada sistem pendidikan salafi.

Kedua, pemimpin pondok pesantren pada umumnya menjadi imam dalam setiap shalat, namun di Pondok Pesantren Riyadlul Ulum Wadda'wah ini berbeda. Perbedaan itu ditunjukkan melalui kegiatan shalat fardhu lima waktu yang diimami oleh ustadz atau santri. Pada posisi ini, pemimpin pondok pesantren menjadi makmum dari para ustadz dan santrinya. Hal ini berbeda dengan kecenderungan pemimpin di pondok pesantren lain. Pemimpin di pondok pesantren lain cenderung selalu menjadi imam di dalam segala kegiatan terutama dalam kegiatan shalat berjamaah.

Kepemimpinan generasi ketujuh baru berjalan kurang dari dua tahun sehingga belum banyak informasi yang diperoleh terkait dengan karakteristik kepemimpinan beliau. Padahal kelebihan dari karakteristik kepemimpinan yang digunakan beliau dapat dijadikan acuan atau teladan bagi calon-calon pemimpin di pondok pesantren tersebut atau bagi calon-calon pemimpin di pondok pesantren lain. Penelitian ini ingin mengetahui dan menganalisis karakteristik kepemimpinan yang diterapkan oleh pemimpin Pondok Pesantren Riyadlul Ulum Wadda'wah Tasikmalaya.

Menurut Armstrong (2009, p.4), "Leadership is the process of getting people to do their best to achieve a desired result." Jadi, kepemimpinan menurut Armstrong adalah sebuah proses membuat orang lain untuk melakukan yang terbaik untuk mencapai hasil yang diinginkan.

Kepemmpinan merupakan sebuah proses yang dilakukan oleh pemimpin. Pengertian pemimpin diutarakan oleh Kartono (2011, p.39), "Pemimpin adalah pribadi yang memiliki kecakapan khusus, dengan atau tanpa pengangkatan resmi dapat mempengaruhi kelompok yang dipim- 
pinnya, untuk melakukan usaha bersama mengarah pada pencapaian sasaran-sasaran tertentu." Definisi ini menekankan pada dua aspek seorang pemimpin, yaitu kecakapan khusus dan proses mempengaruhi. Kedua aspek itu digunakan untuk mencapai sasaran-sasaran tertentu yang sudah disepakati bersama.

Selain pengertian kepemimpinan dan pemimpin tersebut, Rivai \& Arifin (2013, pp.119-120) membandingkan pengertian kepemimpinan dan pemimpin secara bersama-sama agar lebih dapat dibedakan. Pengertian yang dikemukakan ialah kepemimpinan mengacu kepada proses untuk mempengaruhi orang lain, sedangkan pemimpin adalah orang yang dapat menggunakan pengaruh untuk mewujudkan dan mencapai tujuan kelompok. Dengan demikian dapat disimpulkan bahwa kepemimpinan merupakan proses mempengaruhi, sedangkan pemimpin adalah orang yang mempengaruhi.

Menurut Pace \& Faules (2000, p.276), “Tujuan kepemimpinan adalah membantu orang untuk menegakkan kembali, mempertahankan dan meningkatkan motivasi mereka. Jadi, pemimpin adalah orang yang membantu orang lain untuk memperoleh hasil-hasil yang diinginkan." Tujuan kepemimpinan ini menekankan pada penerapan motivasi pada bawahan, sehingga bawahan dapat bekerja secara optimal untuk mencapai tujuan organisasi.

Tujuan kepemimpinan juga diungkapkan oleh Caulfield (2013, p.279) dengan mengatakan "It exists to profoundly connect us to each other in achieving those true narratives that promote the common good by building morally healthy and sustainable local and global communities for the benefit of humanity." Jadi, kepemimpinan ada untuk menghubungkan orang satu sama lain dalam mencapai kebenaran naratif yang mendahulukan kepentingan bersama. Hal tersebut dicapai dengan membangun komunitas lokal dan global yang bermoral, sehat, dan berkelanjutan untuk kepentingan kemanusiaan.

Di sisi lain, agar tujuan dari kepemimpinan tercapai maka pemimpin harus mengetahui perannya. Adair \& Allen (2003, pp.2-3) menyatakan bahwa peran seorang pemimpin terletak pada tiga tanggung jawab inti yang tumpang tindih. Ketiga tanggung jawab ini disebut dengan model fungsi kepemimpinan. Ketiga model fungsi kepemimpinan yang dimaksud berorientasi pada tujuan, tim, dan individu. Berorientasi pada tujuan artinya fungsi kepemimpinan untuk mencapai tujuan organisasi. Berorientasi pada tim yaitu membangun dan memelihara tim. Berorientasi pada individu yaitu memotivasi dan mengembangkan individu. Ketiga model tersebut digambarkan sebagaimana Gambar 1.

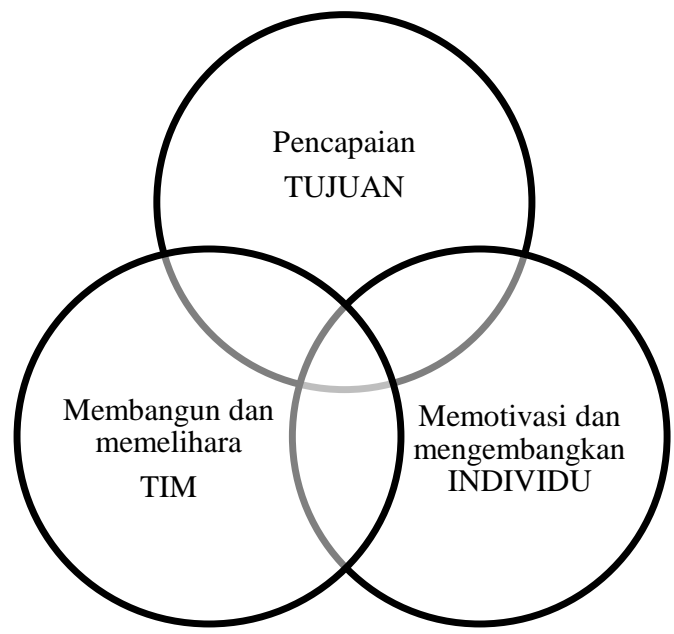

(Sumber: Adair \& Allen, 2003, p.2)

Gambar 1. Model Fungsi Kepemimpinan

Pemanfaatan teori kepemimpinan yaitu melalui peran pemimpin dalam organisasi. Salah satunya adalah organisasi pendidikan yaitu sekolah. Menurut Usman (2013, pp.306-307), setidaknya ada sembilan peran pemimpin pendidikan, terdiri dari: (1) Personnal, yaitu peran ini merujuk pada kualitas diri seorang pemimpin pendidikan yang memiliki kecerdasan intelektual, emosional, dan spiritual; (2) Educator, yaitu seorang pemimpin pendidikan harus dapat merencanakan, melaksanakan, menilai hasil pembelajaran, membimbing, dan melatih; (3) Manager, yaitu pemimpin pendidikan melakukan kegiatan manajemen yaitu merencanakan, mengorganisir, mengarahkan, dan mengawasi; (4) Administrator, yaitu peran yang menuntut pemimpin pendidikan untuk mencapai tujuan sekolah 
melalui pengelolaan ketatausahaan sekolah; (5) Supervisor, yaitu pemimpin pendidikan dituntut agar dapat meningkatkan profesionalisme guru melalui kegiatan perencanaan, pelaksanaan, dan menindaklanjuti hasil supervisi; (6) Orang yang social, yaitu peran pemimpin yang mampu bekerja sama dengan pihak lain di luar organisasinya. Selain itu, pemimpin pendidikan juga harus berpartisipasi dalam kegiatan kemasyarakatan, juga memiliki rasa empati terhadap individu dan kelompok; (7) Leader yaitu pemimpin pendidikan harus mampu memimpin sekolahnya dengan cara mendayagunakan semua sumber daya sekolah secara optimal untuk mencapai tujuan sekolah; (8) Enterpreneur, yaitu peran di mana pemimpin harus kreatif, inovatif, kerja keras, memiliki etos kerja, ulet, dan memiliki naluri kewirausahaan; (9) Climator, yaitu pemimpin pendidikan dituntut untuk menciptakan iklim sekolah yang kondusif.

Keberhasilan dan perubahan yang baik pada sebuah organisasi menjadi cerminan keberhasilan kepemimpinan organisasi tersebut. Dengan kata lain, kepemimpinan yang berhasil adalah kepemimpinan yang efektif. Menurut Bush (2008, p.31), kepemimpinan yang efektif semakin dianggap sebagai komponen penting dari organisasi yang sukses. Pernyataan itu senada dengan Bass (Hoy \& Miskel, 2013, p.418), yang mengatakan bahwa kepemimpinan sering dianggap sebagai salah satu faktor paling penting dalam keberhasilan atau kegagalan lembaga. Di pihak lain, Kartono (2011, p.14) menyatakan bahwa keberhasilan sebuah organisasi dalam mencapai tujuannya tergantung kepada kepemimpinannya. Meski banyak faktor yang menjadi pengaruh terhadap keberhasilan dan kegagalan sebuah organisasi, namun kepemimpinan adalah faktor yang paling kuat dalam mempengaruhi keberhasilan dan kegagalan organisasi (Qomar, 2008, p.273). Berdasarkan pernyataan para ahli tersebut, maka kepemimpinan menjadi salah satu faktor terpenting dalam menentukan keberhasilan sebuah organisasi.

Komariah \& Triatna (2014, p.7) memberikan pendapatnya terkait keefektifan,
"Efektivitas menunjukan ketercapaian sasaran/tujuan yang telah ditetapkan." Dengan demikian, efektif/keefektifan merupakan kesesuaian antara hasil dengan tujuan. Adapun pengertian kata "efektif" dalam kepemimpinan efektif merujuk pada proses mempengaruhi orang lain/bawahan yang menjadi pokok dari kepemimpinan. Nawawi \& Hadari (2012, p.4) mengemukakan bahwa kepemimpinan yang efektif adalah pemimpin yang mampu menggerakan bawahannya untuk mencapai tujuan yang telah ditentukan. Selanjutnya, menurut Blanchard (2010, p.89), "Effective leadership is a transformational journey". Definisi ini memandang kepemimpinan yang efektif sebagai perjalanan transformasi yang melewati empat tahapan, yaitu kepemimpinan diri (self leadership), kepemimpinan satu-satu (one-on-one leadership), kepemimpinan tim (team leadership), dan kepemimpinan organisasi (organizational leadership).

Menjalankan kepemimpinan efektif menjadi sebuah keharusan bagi seorang pemimpin. Pengimplementasian kepemimpinan efektif dapat berdampak baik bagi keberlangsungan organisasi. Di dunia pendidikan, dampak yang muncul di antaranya yaitu dapat meningkatkan prestasi belajar siswa (Chamberlain, 2010, p.102), meningkatkan ketercapaian sekolah (Rousselle, 2013, p.109), dan membangun budaya sekolah yang kuat dan sehat (Wilkey, 2013, p.135).

Menurut Hoy \& Miskel (2013, pp.430-432), ada beberapa ciri dan keterampilan yang berkaitan dengan kepemimpinan yang efektif, yang dapat dibagi menjadi tiga kelompok yaitu: (1) kepribadian: (a) percaya diri, lebih mungkin untuk menetapkan tujuan yang tinggi dan bertahan; (b) stress-tolerance, membuat keputusan yang baik, tetap tenang, memberikan arah yang menentukan di bawah tekanan; (c) kedewasaan emosional, memiliki kesadaran akurat dari kekuatan dan kelemahan, yang berorientasi pada perbaikan diri; (d) integritas, perilaku yang konsisten dengan nilai-nilai lain, seperti halnya para pemimpin dipandang sebagai orang yang jujur, beretika, bertanggung jawab, dan dapat 
dipercaya; (e) extroversion, bersikap ramah, suka bergaul, tidak menghalangi, dan nyaman di dalam kelompok. (2) motivasi: (a) kebutuhan tugas dan interpersonal, pemimpin yang efektif memiliki panduan untuk tugas dan perhatian bagi orangorang; (b) kebutuhan kekuasaan, pemimpin yang efektif mencari posisi otoritas dan menggunakan pengaruh atas orang lain; (c) orientasi prestasi, pemimpin yang efektif memiliki keinginan untuk berprestasi, dorongan untuk berhasil, kesediaan untuk memikul tanggung jawab; (d) harapan yang tinggi untuk sukses, pemimpin yang efektif percaya bahwa mereka dapat melakukan pekerjaan dan akan menerima hasil atas usahanya; (e) keandalandiri, kepercayaan pada diri kita untuk mengorganisir dan menempuh jalur aksi, berkaitan dengan performa pemimpin dan kepemimpinan transformasional. (3) keterampilan: (a) keterampilan teknis, pengetahuan khusus tentang jenis pekerjaan, aktivitas, prosedur, atau teknik tertentu; (b) keterampilan interpersonal, mencakup pemahaman atas perasaan dan sikap orang lain, mengetahui bagaimana bekerja dengan orangorang dalam hubungan kerja individu dan kooperatif; (c) keterampilan konseptual, kemampuan untuk konsep, berpikir logis, dan memberi pertimbangan analitis, deduktif, dan induktif.

Tabel 3. Ciri dan Keterampilan yang Berhubungan dengan

Kepemimpinan Efektif

\begin{tabular}{lcl}
\hline \multicolumn{1}{c}{ Kepribadian } & \multicolumn{1}{c}{ Motivasi } & Keterampilan \\
\hline - Percaya diri & • Kebutuhan & • Teknis \\
- Stress-tolerance & tugas dan & • Interpersonal \\
- Kedewasaan & interpersonal & • Konseptual \\
emosional & - Orientasi & \\
- Integritas & pencapaian & \\
- Extroversion & - Kebutuhan & \\
& kekuasaan & \\
& - Ekspektasi & \\
& - Self-efficacy & \\
\hline
\end{tabular}

Sumber: Hoy \& Miskel (2013, p.430)

Menurut Engku \& Zubaidah (2014, p.115) Pondok pesantren secara etimologi terdiri dari dua kata yaitu pondok yang berarti tempat tinggal dan pesantren ber- arti tempat belajar santri. Sedangkan secara terminologi menurut Damopolii (2011, pp.57-58), pesantren didefinisikan sebagai lembaga pendidikan tradisional Islam untuk mempelajarai, memahami, mendalami, mengahayati, dan mengamalkan ajaran Islam dengan menekankan pentingnya moral keagamaan sebagai pedoman perilaku sehari-hari.

Tan (2011, p.92) mengatakan bahwa pesantren merupakan lembaga pendidikan Islam tertua di Indonesia. Kontribusi pesantren kepada masyarakatpun sangat besar yaitu memberikan pendidikan dan pengajaran sehingga menciptakan masyarakat yang beriman dan berakhlak baik serta membentuk masyarakat yang melek huruf (literacy) dan melek budaya (cultural literacy) (Qomar, 2006, p.xiii).

Model dari kepemimpinan Islam yaitu kepemimpinan yang dijalankan oleh Muhammad Saw. Kepemimpinan yang penuh keistimewaan dan tidak ada seorang pemimpin dari organisasi manapun yang mampu menyamai kepemimpinan beliau. karena kepemimpinan beliau selalu ada dalam bimbingan dan petunjuk Allah Swt yang telah mengangkat dan mengutusnya bagi umat manusia. Menurut Usman (2013, p.338), kepemimpinan Islam memiliki empat sifat yang diwujudkan dalam kepribadian Rasulullah Saw, yang apabila diimplementasikan maka akan menciptakan kepemimpinan yang kuat. Kepemimpinan yang kuat yaitu yang mampu memberdayakan stafnya. Sifat-sifat yang dimaksud yaitu siddiq (jujur, dapat dipercaya), tabligh (mengajak pada kebaikan dan menjauhi kejahatan), amanah (titipan Allah yang harus dipertanggungjawabkan di dunia dan akhirat), fathanah (memiliki kecerdasan intelektual, sosial, emosional, dan spiritual). Keempat sifat tersebut disingkat menjadi STAF.

Kepemimpinan merupakan faktor utama yang menentukan keberhasilan sebuah organisasi, tidak terkecuali bagi lembaga pendidikan pondok pesantren. Kepemimpinan disebuah pondok pesantren menjadi penentu pertumbuhan suatu pondok pesantren (Dhofier, 2011, p.93). 
Pemimpin dalam tradisi pesantren disebut dengan kiai. Kiai adalah seseorang yang memiliki posisi sebagai pemimpin di pesantren/pondok pesantren. Menurut Qomar (2006, p.29), kiai adalah pemimpin nonformal sekaligus spiritual dan posisinya sangat dekat dengan kelompok-kelompok masyarakat lapisan bawah di desadesa. Menurut Damopolii (2011, p.77), kiai adalah tokoh agama yang memiliki sifat yang karismatik. Seorang kiai akan tergantung pada kualitas peribadi, kemampuan, dan kedinamisannya. Dengan demikian, kiai adalah seorang pemimpin pesantren/ pondok pesantren yang memiliki kedalaman ilmu agama dan memiliki kedekatan dengan masyarakat kelas bawah.

Kepemimpinan kiai dalam pondok pesantren menjadi cenderung membangun otoritas mutlak, karena segala sesuatu ditentukan oleh kiai. Dengan kata lain, kepemimpinan kiai dalam pondok pesantren memegang kewenangan mutlak. Selain itu fungsi kiai dalam memimpin pondok pesantren yaitu sebagai pengasuh dan pemilik pondok pesantren (Qomar, 2006, p.31).

Otoritas mutlak yang dilakukan oleh kiai akan dapat dipahami jika dilihat dari akar sejarah pondok pesantren. Pondok pesantren yang didirikan oleh kiai tanpa bantuan atau dengan bantuan masyarakat dan dalam hal lain bersifat tidak mengikat. Akibatnya, kiai bebas menentukan kebijakan-kebijakan yang berhubungan dengan keberlangsungan pendidikan di pondok pesantren, tanpa memperdulikan pihak luar (Qomar, 2006, p.34).

Tugas seorang kiai di pesantren setidaknya ada tiga fungsi. Pertama sebagai guru, kedua sebagai muballigh, dan ketiga sebagai manajer. Kiai sebagai guru yaitu menekankan kepada para santri dan kepada masyarakat sekitar untuk memiliki kepribadian muslim yang utama. Kiai sebagai muballigh ialah kiai selalu berusaha untuk menyampaikan kebaikan kepada setiap orang dan melarang kepada hal-hal yang bertentangan dengan agama Islam (amar ma'ruf nahyil munkar). Adapun fungsi ketiga sebagai manajer adalah kiai meme- rankan pengendalian dan pengaturan pada bawahannya (Qomar, 2008, p.63).

Pada lembaga pendidikan pondok pesantren terutama pesantren salafi, kepemimpinan seorang kiai sangat dipercaya oleh para ustadz dan santri. Hal ini disebabkan karena pertimbangan struktural, teologis, maupun kultural. Secara struktural, kiai memiliki kedudukan yang paling tinggi, boleh dikatakan sebagai raja di dalam kerajaan. Sedangkan dari pertimbangan teologis, kiai dapat mendatangkan kenikmatan dan juga bahaya. Adapun dari pertimbangan kultural, kiai sebagai orang tua, baik karena tua dari faktor usianya maupun dituakan karena kedalaman ilmunya sehingga harus dihormati dan dijadikan panutan/pemimpin (Qomar, 2008, p.65).

Kepemimpinan kiai yang memiliki otoritas penuh, mengakibatkan orang lain tidak diberikan akses untuk mngendalikan sesuatu kecuali dengan izin kiai. Rangkaian kebiasaan yang telah terjadi di pesantren itu menjadikan kiai sebagai sosok pemimpin karismatik. Menurut Waldman, Javidan, \& Varella (Kisling, 2007, p.26), perilaku kunci kepemimpinan karismatik yaitu memberi pengertian tentang misi, menyampaikan visi yang berorientasi pada masa depan dan berdasarkan citra yang kuat, nilai-nilai, dan keyakinan. Kisling (2007, p.26) menambahkan dua perilaku kunci lagi yaitu menunjukkan tekad yang kuat untuk mencapai tujuan dan berkomunikasi tentang ekspektasi kinerja yang tinggi.

Kepemimpinan karismatik yang selama ini dijalankan oleh para kiai pada umumnya menimbulkan beberapa kerugian bagi pondok pesantren. Menurut Abdurrahman Wahid (Qomar, 2008, p.67), setidaknya ada empat kerugian yang ditimbulkan dari kepemimpinan karismatik kiai di pondok pesantren yaitu: (1) ketidakpastian dalam perkembangan pesantren karena semua keputusan tergantung kepada pribadi kiai; (2) keadaan yang kurang mendukung tenaga-tenaga pembantu yang mencoba untuk memunculkan hal-hal baru yang belum dimiliki oleh figur kepemimpinan yang ada; (3) pola pergantian kepe- 
mimpinan terjadi secara tiba-tiba dan tidak direncanakan, sehingga lebih banyak ditandai oleh sebab-sebab alami seperti meninggalnya pemimpin secara mendadak; (4) terjadinya pembaruan dalam tingkattingkat kepemimpinan di pesantren, antara tingkat lokal, regional, dan nasional. Berdasarkan uraian tersebut, dapat disimpulkan bahwa pemimpin di pondok pesantren disebut kiai. Adapun kepemimpinan pondok pesantren cenderung memiliki gaya kepemimpinan karismatik terutama di pondok pesantren salafi.

\section{Metode Penelitian}

Jenis pendekatan penelitian yang digunakan dalam penelitian ini adalah pendekatan kualitatif dengan jenis penelitian fenomenologi. Penelitian fenomenologi karena bertujuan untuk mendapatkan makna di balik data lapangan. Di samping itu, pemilihan fenomenologi juga karena penelitian ini difokuskan kepada satu orang dengan tujuan untuk mendapatkan penjelasan rinci dan pemahaman tentang fenomena kepemimpinan.

Penelitian ini dilaksanakan di Pondok Pesantren Riyadlul Ulum Wadda'wah Kelurahan Condong, Kecamatan Cibeureum, Kota Tasikmalaya, Jawa Barat. Adapun waktu penelitian telah dilaksanakan selama dua bulan yaitu mulai awal Februari sampai dengan akhir

Maret 2016.

Sumber data yang digunakan pada penelitian ini yaitu sumber data primer dan sekunder. Jenis sumber data primer yaitu kata-kata dan tindakan, sehingga untuk mendapatkan datanya menggunakan wawancara dan observasi. Sumber data wawancara didapat melalui responden, yang pada penelitian ini yaitu pemimpin pondok pesantren, wakil pemimpin pondok pesantren, dan perwakilan guru Pondok Pesantren Riyadlul Ulum Wadda'wah Tasikmalaya. Sedangkan teknik penentuan responden dilakukan secara purposive.

Sumber data utama yang berbentuk tindakan diperoleh melalui observasi. Observasi yang dilakukan yaitu observasi par- tisipatif pasif, yaitu peneliti hadir di tempat terjadinya kegiatan yang diobservasi namun tidak ikut serta dalam kegiatan yang sedang berlangsung. Dengan demikian, peneliti dapat mengamati kejadian atau fenomena yang ada di lapangan secara langsung.

Selanjutnya adalah sumber data tambahan, yang diperoleh melalui studi dokumen seperti surat, tabel, bagan, dan foto. Sumber data ini dikaji oleh peneliti untuk menemukan data dari dokumen-dokumen tersebut. Dokumen-dokumen yang dibutuhkan oleh peneliti adalah dokumen-dokumen yang dapat menunjang dan relevan dengan penelitian.

Teknik pengumpulan data yang dilakukan dalam penelitian ini melalui tiga sumber yaitu: (1) wawancara, (2) observasi, (3) dan studi dokumen. Instrumen kunci dalam penelitian kualitatif adalah peneliti itu sendiri. Peneliti mengumpulkan sendiri data yang diperoleh dari wawancara, observasi, dan studi dokumen. Namun demikian, peneliti menggunakan pedoman dari masing-masing teknik pengumpulan data. Analisis data kualitatif yang digunakan pada penelitian ini yaitu mengacu kepada model interaktif yang dikemukakan oleh Miles \& Huberman (1994, p.12). Tahapan analisis data yang dimaksud terdiri dari tiga tahapan. Ketiga tahapan itu disajikan seperti pada Gambar 2.

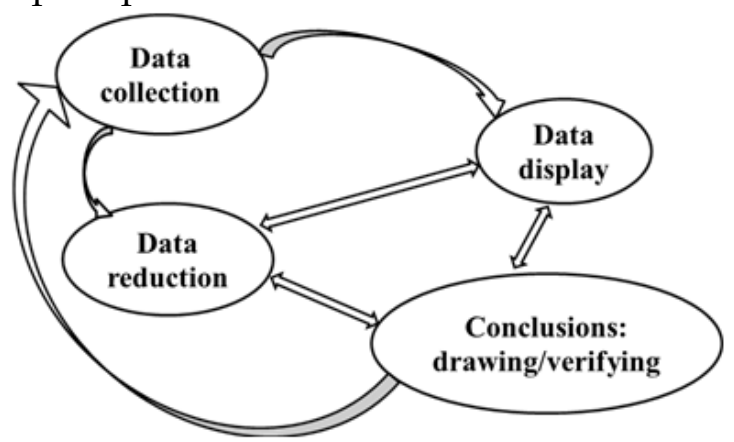

(Miles \& Huberman, 1994, p.12)

Gambar 2. Komponen Analisis Data: Model Interaktif

\section{Hasil Penelitian dan Pembahasan}

Karakteristik Kepribadian

Karakteristik kepribadian kepemimpinan kiai yang diperoleh pada penelitian 
ini yaitu arif yang artinya cerdas dalam bersikap, memiliki keyakinan untuk mencapai keberhasilan, dan tawadhu dibuktikan dengan sikap kiai yang tidak ingin diposisikan sebagai orang yang memiliki otoritas penuh terhadap segala sesuatu, seperti mengizinkan santrinya untuk menjadi imam shalat fardhu dan khatib shalat Jum'at.

Menurut Yani (2009), tawadhu adalah rendah hati atau tidak sombong. Tawadhu dalam artian mendalam yaitu ketika seseorang tidak memandang manusia yang lain lebih rendah dibandingkan dengan dirinya. Selanjutnya, terdapat beberapa ciri orang yang tawadhu yaitu: menyadari bahwa semua kenikmatan yang didapatnya bersumber dari Allah Swt, tidak pernah terbersit sedikitpun dalam hatinya kesombongan dan merasa lebih baik dari orang lain, tidak merasa bangga dengan potensi dan prestasi yang sudah dicapainya, tetap rendah diri dan selalu menjaga hati dan niat segala amal shalehnya dari segala sesuatu selain Allah Swt, tetap menjaga keikhlasan amal ibadahnya hanya karena Allah Swt, bersikap tenang, sederhana dan sungguh-sungguh menjauhi perbuatan takabur (sombong) atau amal kebaikannya ingin diketahui orang lain.

Hasil penelitian ini berbeda dengan teori yang dikemukakan oleh Abdurrahman Wahid (Qomar, 2008, p.67) yang mengatakan bahwa setidaknya ada empat kerugian yang ditimbulkan dari kepemimpinan karismatik kiai. Namun demikian, terdapat dua perbedaan dengan hasil penelitian ini yang berkenaan dengan karakteristik kepribadian yaitu ketidakpastian dalam perkembangan pesantren karena semua keputusan tergantung kepada pribadi kiai dan keadaan yang kurang mendukung tenaga-tenaga pembantu yang mencoba untuk memunculkan hal-hal baru yang belum dimiliki oleh figur kepemimpinan yang ada.

Pada kenyataannya kiai memberikan kebebasan kepada pembantunya untuk memunculkan kreativitas dan gagasangagasan baru selama tidak bertentangan dengan norma pondok pesantren. Hal ter- sebut juga dibuktikan dengan pemberian kewenangan kepada bagian-bagian di pondok pesantren untuk membuat program.

\section{Karakteristik Motivasi}

Berdasarkan hasil penelitian maka ditemukan bahwa karakteristik motivasi kepemimpinan kiai DDF meliputi: amanat dari pemimpin sebelumnya, kewajiban untuk terus berdakwah lii'laikalimaatillah, kemajuan dan keberhasilan yang dicapai oleh pondok pesantren, serta minat dan kepercayaan masyarakat yang dari tahun ke tahun terus meningkat. Berdasarkan karakteristik motivasi tersebut, motivasi yang timbul pada diri kiai terdiri dari motivasi intrinsik dan ekstrinsik. Intrinsik seperti kewajiban untuk berdakwah, sedangkan ekstrinsik seperti amanat yang diberikan, kemajuan dan keberhasilan yang dicapai, dan minat dan kepercayan dari masyarakat.

Selanjutnya hasil penelitian ini memiliki kesamaan dengan ciri motivasi yang disebutkan oleh Hoy \& Miskel (2013, pp.430-432) di antaranya: (1) kebutuhan tugas dan interpersonal: pemimpin yang efektif memiliki panduan untuk tugas dan perhatian bagi orang-orang; (2) orientasi prestasi: pemimpin yang efektif memiliki keinginan untuk berprestasi, dorongan untuk berhasil, kesediaan untuk bertanggung jawab; (3) harapan yang tinggi untuk sukses: pemimpin yang efektif percaya bahwa mereka dapat melakukan pekerjaan dan akan menerima hasil atas usahanya.

\section{Karakteristik Keterampilan}

Hasil penelitian tentang keterampilan kepemimpinan yang dikuasai oleh kiai DDF yaitu: memberi contoh dalam beribadah, mengajar, keterampilan dalam bertani/berkebun, keterampilan dalam beternak, dan berfokus pada peningkatan keterampilan santri agar menjadi bekal di masyarakat. Gagasan-gagasan yang muncul dari kepemimpinannya ialah: pengajian bulanan guru, berjamaah dan tausiyah Subuh dan Magrib bagi guru dan kelas XII, dan pengajian bagi orang tua santri. Sedangkan upaya yang ditempuh oleh pe- 
mimpin pondok untuk meningkatkan keterampilannya dalam memimpin yaitu: belajar mandiri dengan memuthola'ah kitab/buku dan meminta masukan dari para pembantunya.

Yukl (2010, p.12) yang menyebutkan karakteristik kepemimpinan efektif dapat dilihat melalui karakteristik pemimpin, pengikut, dan situasi. Ketiga komponen itu memiliki karakteristik tertentu. Adapun karakteristik dari pemimpin meliputi. (1) ciri (motivasi, kepribadian, nilai); (2) keyakinan dan optimisme; (3) keterampilan dan keahlian, (4) perilaku; (5) Integritas dan etika; (6) Taktik pengaruh, (7) Sifat pengikut.

Hasil konferensi internasional (Asia Society, 2012, p.19) dengan tema pengajaran dan kepemimpinan untuk abad ke-21, yang diselenggarakan di Amerika Serikat menyebutkan bahwa terdapat empat jenis tanggung jawab kepemimpinan yang erat kaitannya dengan peningkatan hasil siswa, yakni sebagai berikut: (1) mendukung, mengevaluasi, dan mengembangkan kualitas guru sebagai kunci keberhasilan siswa. (2) menetapkan tujuan sekolah untuk kinerja siswa, mengukur kemajuan, dan membuat perbaikan; (3) menggunakan sumber daya strategis agar berfokus pada kegiatan peningkatan pengajaran dan pembelajaran; (4) menjalin kemitraan dengan masyarakat, lembaga sosial, dan universitas untuk mendukung pengembangan seluruh siswa.

Hammond, Meyerson, LaPointe, \& Orr. (2010, p.115) menyatakan bahwa praktik kepemimpinan efektif dapat diukur melalui skala seberapa sering mereka melakukan sepuluh kegiatan berikut: (1) memfasilitasi belajar siswa; (2) membimbing kurikulum dan pengajaran; (3) membangun komunitas profesional-learning; (4) membina pengembangan profesional guru; (5) mengevaluasi dan memberikan umpan balik kepada guru; (6) menggunakan data dalam mengelola dan memperbaiki sekolah; (7) bekerja sama dengan orang tua untuk memenuhi kebutuhan siswa; (8) bekerja sama dengan staf pengajar untuk memecahkan masalah; (9) membantu staf pengajar me- ngembangkan tujuan praktik dan pembelajaran profesional; (10) bekerja dengan guru untuk mengubah metode pengajaran ketika siswa tidak berhasil.

\section{Karakteristik Dominan}

Hasil penelitian menunjukkan bahwa karakteristik dominan dari kepribadian kepemimpinan kiai DDF yaitu tawadhu dan amanah. Selanjutnya, karakteristik dominan dari motivasi kepemimpinan kiai DDF yaitu menjalankan amanah dari pemimin sebelumnya. Kemudian, karakteristik dominan ketiga dari karakteristik keterampilan kepemimpinan kiai DDF yaitu berfokus pada peningkatan pendidikan dan pengajaran.

Rivai \& Arifin (2013, p.85) mengatakan bahwa setidaknya terdapat lima prinsip yang harus diikuti oleh pemimpin supaya bawahan mau bekerja secara optimal. Kelima prinsip itu terdiri dari: prinsip partisipasi, prinsip komunikasi, prinsip mengakui andil bawahan, prinsip pendelegasian wewenang,dan prinsip memberikan perhatian timbal balik.

Karakteristik dominan dari kepribadian kepemimpinan sejalan dengan perilaku pemimpin yang demokratis dalam perilaku sosial yang memiliki ciri: kebijakan dirumuskan melalui musyawarah dan pemimpin sebagai pendorong, menetapkan kegiatan secara bersama-sama untuk mencapai tujuan organisasi, membebaskan anggota untuk bekerja sama dengan siapapun, dan memberikan penghargaan dan kritik secara objektif (Usman, 2013, p.357).

Hasil penelitian ini memiliki perbedaan dibandingkan dengan pemimpin pondok pesantren pada umumnya, sebagai mana yang diungkapkan oleh Qomar (2006, p.31) dan Abdurrahman Wahid (Qomar, 2008, p.67). Qomar (2006, p.31) mengatakan bahwa kepemimpinan kiai dalam pondok pesantren menjadi cenderung membangun otoritas mutlak. Di pihak lain Abdurraman Wahid (Qomar, 2008, p.67) memberi pendapat yang sama dengan mengatakan bahwa semua keputusan tergantung kepada pribadi kiai. Kekhasan dari hasil penelitian ini adalah pemimpin Pondok Pesantren 
Riyadlul Ulum Wadda'wah menerapkan kepemimpinan yang tawadhu yaitu selalu memberikan kesempatan kepada santrinya untuk menjadi imam shalat fardhu dan khatib shalat Jum'at.

Menurut Bush (2008, p.18), model kepemimpinan instruksional sangat berkaitan dengan proses belajar mengajar, termasuk pembelajaran guru profesional serta pertumbuhan siswa. Kepemimpinan instruksional berfokus pada pengajaran dan pembelajaran dan pada perilaku guru dalam bekerja dengan siswa. Berdasarkan teori tersebut, kiai DDF telah melakukan karakteristik kepemimpinan instruksional dalam kepemimpinannya di pondok pesantren.

Hasil penelitian ini juga berbeda dengan pernyataan yang dikemukakan oleh Dhofier (2011, p.42), yang mengatakan bahwa sembahyang dan khutbah Jum'at merupakan aktivitas yang dilakukan oleh kiai sebagai contoh tingkah laku yang benar secara Islam. Di pondok pesantren pada umumnya, imam shalat fardhu dan khatib Jum'at dibawakan oleh kiai. Namun keadaan tersebut berbeda dengan pondok pesantren yang menjadi tempat penelitian ini. Di Pondok Pesantren Riyadlul Ulum Wadda'wah, imam shalat fardhu yaitu siswa kelas XII atau guru, sedangkan khatib Jum'at dibawakan oleh siswa kelas XII. Adapun posisi pimpinan pada saat shalat fardhu atau khutbah Jum'at yaitu sebagai makmum. Berdasarkan hasil observasi, pemimpin pondok menjadi makmum shalat fardhu dan shalat Jum'at dan berbaur dengan para santri. Tujuannya yaitu sebagai bekal keterampilan bagi para santri ketika terjun ke masyarakat.

Apabila diruntut dari dari karakteristik keseluruhan, maka akan ditemukan sifat-sifat kepemimpinan Islam pada kiai DDF. Siddiq artinya jujur dibuktikan dengan pernyataan beliau yang selalu diiyakan oleh para pembantunya. Tabligh dibuktikan dengan dakwah beliau terhadap santri dan guru melalui tausiyah dan Akhlak alKarimah. Amanah dengan mengemban tanggung jawab yang diberikan pemimpin terdahulu. Fathanah dituangkan melalui gagasan-gagasan yang muncul darinya (kecer- dasan intelektual), menjalin hubungan baik dengan masyarakat (kecerdasan sosial), tidak mudah marah (kecerdasan emosional), dan rajin beribadah (kecerdasan spiritual). Keempat karakteristik kiai tersebut disingkat STAF.

\section{Keterbatasan Penelitian}

Meski penelitian ini telah dilakukan secara optimal, namun masih memiliki beberapa keterbatasan sebagai berikut: (1) ada beberapa materi rapat yang tidak dapat diikuti oleh peneliti, hal itu dikarenkan materi yang bersangkutan bersifat rahasia internal pondok pesantren; (2) masih kurang terbukanya responden dalam menjawab pertanyaan wawancara yang diberikan oleh peneliti. Hal tersebut dikarenakan kiai yang memiliki sifat thawadu tidak ingin mengungkapkan semua karakteristik yang dimilikinya. (3) terbatasnya jurnal penelitian internasional yang berkaitan dengan kepemimpinan kiai menjadi kendala dalam penambahan referensi.

\section{Simpulan dan Saran}

Simpulan

Berdasarkan hasil penelitian tentang Karakteristik Kepemimpinan Kiai di Pondok Pesantren Riyadlul Ulum Wadda'wah Tasikmalaya dapat disimpulkan sebagai berikut. Karakteritik kepribadian kepemimpinan kiai yaitu tawadhu dan amanah. Makna lain dari temuan tersebut adalah pemimpin tidak mau menonjolkan diri, rendah hati yang dibuktikan dengan sikap kiai yang tidak ingin diposisikan sebagai orang yang memiliki otoritas penuh terhadap segala sesuatu, seperti mengizinkan santrinya untuk menjadi imam shalat fardhu dan khatib shalat Jum'at, serta regenerasi. Dalam kepemimpinan Islam hal tersebut termasuk dalam karakteristik Siddiq (jujur, benar). Selanjutnya, kebijaksanaan terjadi sebagai kepribadian kiai karena sudah menjadi tradisi untuk melanjutkan kepemimpinan sebelumnya. Pemimpin pondok pesantren juga memaknai kemajuan yang dicapai oleh pondok pesantren merupakan hasil dari kebijaksanaan pemimpinnya. 
Karakteristik motivasi kepemimpinan kiai meliputi: motivasi intrinsik dan ekstrinsik. Motivasi intrinsik terjadi karena kewajiban untuk terus berdakwah lii'laikalimaatillah melalui pengasuhan santri dan memimpin pondok pesantren. Karakteristik ini di dalam kepemimpinan Islam termasuk sifat Tabligh (menyampaikan). Adapun motivasi ekstrinsik terjadi karena menjalankan amanat dari pemimpin sebelumnya, kemajuan dan keberhasilan yang dicapai oleh pondok pesantren, serta minat dan kepercayaan masyarakat yang terus meningkat. Makna dari karakteristik motivasi tersebut adalah kepemimpinan merupakan sebuah tanggung jawab yang harus dijalankan. Tanggung jawab yang diberikan bukan saja dari pemimpin sebelumnya dan orang tua santri, tetapi pada hakikatnya dari Allah Swt.

Keterampilan yang dikuasai oleh kiai meliputi: keterampilan teknis, seperti mengajar, bertani/berkebun, dan beternak; keterampilan interpersonal seperti menjadi teladan dalam beribadah bagi para santri dan guru di pondok pesantren; keterampilan konseptual dibuktikan melalui gagasangagasan baru dalam pendidikan dan pengajaran bagi para santri, guru, dan orang tua santri, ini juga yang dinamakan sebagai sifat kepemimpinan Islam yaitu Fathanah (cerdas). Berdasarkan karakteristik tersebut, pemimpin saat ini berfokus pada pembelajaran dan peningkatan keterampilan santri, bertindak sebagai educator, dan memiliki jiwa entrepreneur. Makna dari karakteristik keterampilan tersebut adalah pemimpin ingin menciptakan santri yang siap guna di masyarakat, bukan saja di bidang pengetahuan agama tetapi juga pengetahuan umum dan keterampilan hidup (life skill).

Karakeristik dominan dari karakteristik kepribadian yaitu sifat beliau yang bijaksana dibuktikan dengan kecenderungan kepemimpinan yang demokratis. Karakteristik dominan dari motivasi kepemimpinan kiai yaitu tekad yang kuat untuk melanjutkan amanah dari pemimpin sebelumnya. Hal tersebut mencerminkan sikap kepemimpinan yang sesuai dengan sifat kepemimpinan Islam yaitu Amanah (dapat dipercaya). Karakteristik dominan dari keterampilan kepemimpinan beliau yaitu berfokus pada peningkatan pendidikan dan pengajaran untuk meningkatkan keterampilan santri, Makna dari temuan tersebut adalah pemimpin menyadari akan pentingnya kebersamaan dan keikutsertaan semua pihak dalam mengelola pondok pesantren. Pemimpin menyadari kepercayaan yang diberikan kepadanya merupakan sebuah tanggung jawab besar yang harus dilaksanakan. Pemimpin menyadari besarnya tantangan dan tuntutan di masyarakat, sehingga perlu menciptakan santri yang dapat menjawab tantangan dan tuntutan tersebut yaitu melalui pengajaran pengetahuan agama, umum, dan kecakapan hidup (life skill).

Berdasarkan uraian tersebut, maka kepemimpinan yang diterapkan oleh kiai mengacu kepada kepemimpinan Islam yaitu Siddiq, Tabligh, Amanah, dan Fathanah, yang disingkat STAF.

\section{Saran}

Berdasarkan kesimpulan penelitian maka saran yang dapat diberikan sebagai berikut. Pertama, bagi Kiai/Pemimpin Pondok Pesantren yakni: (1) Kiai perlu meningkatkan budaya berpendapat di lingkungan pondok pesantren; (b) Kiai perlu menjaga keharmonisan di pondok pesantren. Keharmonisan dapat dijaga dengan mempertahankan karakteristik dominan kiai yang sopan, rendah hati, dan lemah lembut; (c) Kiai perlu meningkatkan akuntabilitas pengelolaan pondok pesantren untuk menjaga kepercayaan masyarakat terhadap pondok pesantren.

Kedua, bagi Lembaga Pondok Pesantren yakni: (a) karakteristik kepemimpinan kiai saat ini dapat dijadikan sebagai kualifikasi dalam memilih kader pimpinan pondok pesantren selanjutnya. (b) karakteristik kepemimpinan kiai saat ini dapat dijadikan teladan bagi seluruh warga pondok pesantren; (c) motivasi dakwah dan amanah dalam kepemimpinan kiai dapat diikuti oleh seluruh warga pondok pesantren dalam pengelolaan pondok pesantren. 


\section{Daftar Pustaka}

Adair, J. \& Allen, M. (2003). Time management and personal development. London: Thorogood Publishing, Ltd.

Armstrong, M. (2009). Armstrong's handbook of management and leadership: A guide to managing for results. Second Edition. London: Kogan Page.

Asia Society. (2012). Teaching and leadership for the twenty-first century: The 2012 international summit on the teaching profession. New York City.

Blanchard, K. (2010). Leading at a higher level: Blanchard on leadership and creating high performing organizations. Upper Saddle River, New Jersey: Pearson Prentice Hall.

Bush, T. (2008). Leadership and management development in education. London: SAGE.

Caulfield, J. (2013). Why does leadership exist?. Journal of Leadership Education. Vol. 12, Issue 1. 274-281.

Chamberlain, P. J. (2010). An exploration of leadership capacity building and effective principal practices. ProQuest. Jurnal.

Damopolii, M. (2011). Pesantren modern IMMIM pencetak Muslim modern. Jakarta: Rajawali Pers.

Dhofier, Z. (2011). Tradisi pesantren: Studi pandangan hidup kyai dan visinya $m$ engenai masa depan Indonesia. Jakarta: LP3ES.

Engku, I. \& Zubaidah, S. (2014). Sejarah pendidikan Islam. Bandung: Remaja Rosdakarya.

Hammond, L. D., Meyerson, D., LaPointe, M., \& Orr, M. T. (2010). Preparing principals for a changing world. San Francisco: Jossey-Bass.

Hoy, W. K. \& Miskel, C. G. (2013). Educational administration: Theory, research, and practice. New York: McGrawHill.
Kartono, K. (2011). Pemimpin dan kepemimpinan: Apakah kepemimpinan abnomal itu?. Jakarta: Rajawali Pres.

Kementerian Agama. (2014). Peraturan menteri agama nomor 18 tahun 2014 tentang satuan pendidikan muadalah pada pondok pesantren.

Kementerian Agama Provinsi Jawa Barat. (2014). Rekapitulasi data pontren. Diambil pada tanggal 25 Juni 2015, dari

http://jabar.kemenag.go.id/index. php?a $=$ artikel $\& \mathrm{id}=27592 \& \mathrm{t}=4912 \& \mathrm{t}$ $=4912 \& \mathrm{t}=4912$

Kisling, R. A. (2007). Character for leadership: The role of personal characteristics in effective leadership behaviors. ProQuest. Jurnal.

Komariah, A. \& Triatna, C. (2014). Visionary leadership: Menuju sekolah efektif. Jakarta: Bumi Aksara.

Miles, M. B. \& Huberman, A. M. (1994). Qualitative data analysis. Second Edition. London: SAGE.

Nawawi, H. \& Hadari, M. M. (2012). Kepemimpinan yang efektif. Yogyakarta: Gadjah Mada University Press.

Pace, R. W. \& Faules, D. F. (2000). Komunikasi organisasi: Strategi meningkatkan kinerja perusahaan. (Terjemahan Deddy Mulyana). Bandung: Remaja Rosdakarya.

Qomar, M. (2006). Pesantren: dari transformasi metodologi menuju demokratisasi institusi. Jakarta: Penerbit Erlangga.

Qomar, M. (2008). Manajemen pendidikan Islam. Jakarta: Penerbit Erlangga.

Rivai, V. \& Arifin, A. (2013). Islamic leadership: Membangun super leadership melalui kecerdasan spiritual. Jakarta: Bumi Aksara.

Rousselle, L. M. (2013). Examining school climate and effective leadership in relation to school success. ProQuest. Jurnal. 
Syihabuddin, B. \& Romadhoni, B. S. (2015). Selayang pandang pondok pesantren Condong. Tasikmalaya: Pondok Pesantren Riyadlul Ulum Wadda'wah.

Tan, C. (2011). Islamic education and indoctrination: The case in Indonesia. New York: Routledge.

Usman, H. (2013). Manajemen: Teori, praktik, dan riset pendidikan. Jakarta: Bumi Aksara.

Wilkey, G. G. (2013). Research into the characteristics of effective high school principals: A case study of leadership practices used in the high school setting. ProQuest. Jurnal.

Yani, D. (2009). Tawadhu. Diambil pada tanggal 4 Mei 2016, dari https://jalandakwahbersama.word press.com/2009/06/09/tawadhurendah-hati/

Yukl, G. (2010). Leadership in organizations. Seventh Edition. Upper Saddle River, New Jersey: Pearson Prentice Hall. 